\title{
Pengembangan Instrumen Manajerial Dan Komunikasi Terhadap Kinerja Dosen Perguruan Tinggi Keagamaan Islam Swasta (PTKIS) Di Padangsidempuan
}

\author{
Melda Diana Nasution \\ Sekolah Tinggi Agama Islam Nageri Mandailing Natal, Sumut, Indonesia \\ Email : meldadiana83@gmail.com
}

\begin{abstract}
Abstrak
Instrumen penelitian merupakan faktor yang terpenting dalam sebuah penelitian. Pada Instrumen penelitian itulah letaknya sebuah kebenaran akan hasil yang diteliti sebelum di tarik sebuah kesimpulan, jika Instrumennya salah maka Instrumen tersebut tidak dapat mengukur apa yang sepatutnya di ukur. Penelitian ini merupakan penelitian lapangan dengan menggunakan sampel ada 30 orang. Data dianalisis dengan menggunakan SPSS Versi 23.00 for Windows untuk melihat konsistensi internal dengan menggunakan Cronbach Alpha. Hasil dari penelitian ini, semua item kuisioner valid dan reliabel dengan rata-rata nilai realibilitas Cronbach Alpha Manajerial Ketua Perguruan Tinggi adalah valid, karena nilai $r$ hitung lebih besar dari $r$ tabel $=0,707$. Hasil uji reliabilitas data menunjukkan semua butir pernyataan dari Kuesioner Manajerial Ketua Perguruan Tinggi adalah reliabel, karena nilai $r{ }_{11}=0,966>0,6$. Hasil uji reliabilitas data menunjukkan semua butir pernyataan dari Kuesioner Komunikasi Ketua Perguruan Tinggi adalah reliabel, karena nilai $r_{11}=0,973>0,6$. Hasil uji reliabilitas data menunjukkan semua butir pernyataan dari Kuesioner Kinerja Dosen adalah reliabel, karena nilai $r_{11}=0,974>0,6$
\end{abstract}

Keywords: Instrumen, Manajerial Dan Komunikasi, Kinerja Dosen, PTKIS

\begin{abstract}
The research instrument is the most important factor in a study. In this research instrument lies the truth of the results studied before drawing a conclusion, if the instrument is wrong then the instrument cannot measure what should be measured. This research is a field research using a sample of 30 people. Data were analyzed using SPSS Version 23.00 for Windows to see internal consistency using Cronbach Alpha. The results of this study, all questionnaire items are valid and reliable with an average reliability value of Cronbach Alpha Managerial Head of Higher Education is valid, because the value of $r$ count is greater than $r$ table $=0.707$. The results of the data reliability test showed that all statement items from the Managerial Questionnaire of the Head of Higher Education were reliable, because the value of r $11=0.966>0.6$. The results of the data reliability test showed that all statements from the Head of Higher Education Communication Questionnaire were reliable, because the value of $r$ $11=0.973>0.6$. The results of the data reliability test show that all statement items from the Lecturer Performance Questionnaire are reliable, because the value of $r 11=0.974>0.6$.
\end{abstract}

Keywords: Instruments, Managerial and Communication, Lecturer Performance, PTKIS

\section{Pendahuluan}

Dosen merupakan kunci utama untuk meningkatkan kualitas pendidikan,karena persyaratan penting bagi terwujudnya pendidikan yang bermutu adalah apabila pelaksanaannya dilakukan oleh dosen yang keprofesionalannya dapat diandalkan. Dosen juga 
merupakan salah satu tenaga kependidikan yang mempunyai peranan yang sangat vital dalam dunia pendidikan khususnya pendidikan formal, karena seorang dosen yang langsung bersinggungan dengan siswa, untuk memberikan bimbingan yang muaranya akan menghasilkan tamatan yang diharapkan. Untuk itu kinerja seorang dosen harus selalu ditingkatkan. Sementara kinerja dosen dapat ditingkatkan apabila yang bersangkutan mengetahui apa yang diharapkan dan kapan bisa menetapkan harapan-harapan yang diakui hasil kerjanya.

Perguruan Tinggi dan administrasi pembelajaran, melaksanakan bimbingan dan layanan pada para siswa, serta melaksanakan penilaian (Tabrani Rusyan dkk, 2019). Dalam penelitian ini penulis mencoba mengkaji fenomena yang terjadi pada ketua/Rektor serta dosen yang ada di Perguruan Tinggi Islam yang ada di Kota Padang Sidempuan. Untuk mewujudkan pengelolaan yang baik diperguruan tinggi, maka ketua/Rektor sebagai seorang manajer harus mempunyai kemampuan profesional di bidangnya. Kualitas pengelolaan Perguruan Tinggi akan tergantung kepada seorang ketua/Rektor yang berperan sebagai manajer. Sebagai seorang manajer, ketua/Rektor tentu mempunyai tugas dan tanggung jawab yang besar dalam mengelola perguruantingginya.

Melakukan peran dan fungsinya sebagai manajer ketua/Rektor harus mampu memiliki strategi yang tepat untuk mengoptimalkan tenaga kependidikan melalui kerja sama atau kooperatif, dan medorong keterlibatan seluruh tenaga pendidik dalam berbagai kegiatan yang menunjang program Perguruan Tinggi (E .Mulyasa, 2011). Keberhasilan ketua/Rektor dalam melaksanakan tugas-tugasnya dipengaruhi oleh berbagai faktor, diantaranya faktor partisipasi masyarakat, Perguruan Tinggi dan dukungan dari berbagai pihak. Dengan adanya keterlibatan dosen dan masyarakat dalam meningkatkan kualitas pendidikan akan sangat membantu tugas-tugas kepala Perguruan Tinggi. Oleh karena itu kualitas dosen harus terus ditingkatkan untuk dapat menjalankan tugas dengan sebaik-baiknya.

Ketua/Rektor dituntut untuk memiliki kesiapan dalam mengelola Perguruan Tinggi, kesiapan pimpinan yang dimaksud adalah kemampuan manajerial sesuai dengan Peraturan Menteri Riset, Teknologi, Dan Pendidikan Tinggi Republik Indonesia Nomor 1 Tahun 2016 2015 Tentang Perubahan Atas Peraturan Menteri Riset, Teknologi, Dan Pendidikan Tinggi Nomor 1 Tahun 2015 Tentang Pengangkatan Dan Pemberhentian Rektor/Ketua/Direktur Pada Perguruan Tinggi Negeri Pendidikan Nasional RI No 13 Tahun 2007 Tentang Standar Ketua Perguruan Tinggi, kemampuan manajerial ketua/Rektor meliputi perencanaan, pengorganisasian, dan pengawasan. Dengan kemampuan manajerial yang baik diharapkan setiap ketua/Rektor mampu menjadi pendorong bagi dosen untuk dapat meningkatkan kinerja.

Sebagaimana teori yang telah dijabarkan tersebut, menurut pengamatan/observasi yang dilakukan oleh penulis pada tanggal 20-23 Juni 2021, penulis melihat bahwa ketua/Rektor di PTKIS Kota Padang Sidempuan, belum memiliki kompetensi manajerial dan komunikasi yang baik. Kompetensi manajerial yang dimiliki ketua/Rektor di PTKIS Kota Padang Sidempuan, dibuktikan dengan antara lain:a) Ketua/Rektor belum mampu membuat konsep (perencanaan) program kerja, ketua/Rektor belum mampu berfikir rasional, cakap dan cekatan; b) Ketua/Rektor belum mampu mengenali dan mengantisipasi masalah dan mampu memberi arahan; c)Ketua/Rektor belum mampu mengkoordinasikan membagi tugas dan tanggung jawab; d) Ketua/Rektor belum memiliki kemampuan memahami sikap atau perilaku manusia dan proses kerja sama.

Begitupun dengan kemampuan komunikasi yang dimiliki oleh ketua/Rektor di PTKIS Kota Padang Sidempuan ini, dapat dibuktikan diantaranya antara lain; a) Adanya informasi- 
informasi yang diberikan oleh ketua/Rektor kepada bawahannya baik secara langsung maupun tidak langsung seperti dengan memberikan pesan di dalam grup media sosial whatsapp dan messenger atau telepon belum jelas dan transparan; b) Ketua/Rektor memberikan keputusan dalam kegiatan rapat yang telah dimusyawarahkan; c) Ketua/Rektor membantu dalam memecahkan permasalahan yang dihadapi dosen; d) Ada dosen yang masih kurang memahami dengan informasi yang telah disampaikan oleh ketua/Rektor sehingga terkadang tidak dijalankan tugasnya; e) Ketua/Rektor menginstruksikan program kerja dosen serta memberikan ide serta pendapat kepada bawahannya agar kinerja nya bertambah semakin baik dan bermutu, Akan tetapi meskipun indikasi kompetensi manajerial ketua/Rektor dan komunikasi ketua/Rektor sudah terlihat baik namun masih perlu adanya peningkatan kinerja dosen di PTKIS Kota Padang Sidempuan. Tampak karena penulis masih menemukan gejala-gejala seperti;a) Masih terdapat dosen yang belum mengoptimalkan rencana program pembelajaran dalam kegiatan belajar mengajar;b) Masih ada beberapa dosen yang dalam melaksanakan tugasnya tidak dilandasi dengan tanggung jawab dalam artian dosen hanya menyampaikan materi saja tanpa memperhatikan kondisi siswa; c) Kepala madrsah sudah selalu memberikan masukan-masukan dan mengevaluasi kegiatan.

pembelajaran yang dilakukan dosen serta ketua/Rekto rmemberikan umpan balik kepada dosen dengan memanggil secara pribadi setelah dilakukan evaluasi; d) Kurangnya evaluasi dosen terkait pembelajaran yang telah disampaikan kepada mahasiswa; e) Masih ada beberapa dosen yang melakukan evaluasi hanya ketika diadakannya ujian tengah semester atau ujuan akhir semester saja; f) Ada beberapa dosen yang hanya kurang menguasai/ mengelola kelas sehingga siswa kurang antusias dan semangat dalam belajar; g) Beberapa dosen masih terlalu banyak menggunakan metode berceramah sehingga murid hanya pasif tidak aktif dalam belajar; h) Masih ada beberapa dosen yang kurang mahir dalam menggunakan media maupun metode dalam pembelajaran sehingga siswa kurang besemangat dan aktif dalam belajar; i) Masih terdapat dosen yang tidak menguasai berbagai macam metode pembelajaran, hanya menggunakan metode ceramah saja.

Berdasarkan pembatasan masalah diatas maka dapat dirumuskan permasalahan penelitian ini yaitu: 1) Bagaimana Kemampuan Manajerial Ketua Terhadap Kinerja Dosen Perguruan Tinggi Keagamaan Islam Swasta (PTKIS) di Kota Padang Sidempuan?; 2)Kemampuan Komunikasi Ketua Terhadap Kinerja Dosen Perguruan Tinggi Keagamaan Islam Swasta (PTKIS) di Kota Padang Sidempuan?; 3)Faktor-faktor yang mempengaruhi Kemampuan Manajerial dan Komunikasi Ketua Terhadap Kinerja Dosen Perguruan Tinggi Keagamaan Islam Swasta (PTKIS) di Kota Padang Sidempuan?

adalah penelitian yang menjelaskan fakta apa adanya" (Prasetya Irawan, 1999). Penelitian kualitatif merupakan penelitian yang temuannya diperoleh berdasarkan paradigma, strategi dan implementasi model secara kualitatif (Aminuddi, tt). Sedangkan menurut Manca seperti yang dikutip oleh Moleong, Penelitian kualitatif memiliki ciri-ciri sebagai berikut: (1) Merupakan tradisi Jerman yang berlandaskan idealisme, humanisme, dan kulturalisme; (2) penelitian ini dapat menghasilkan teori, mengembangkan pemahaman, dan menjelaskan realita yang kompleks; ( 3) Bersifat dengan pendekatan induktif-deskriptif; (4) memerlukan waktu yang panjang; (5) Datanya berupa deskripsi, dokumen, catatan lapangan, foto, dan gambar; (6) Informannya "Maximum Variety"; (7) berorientasi pada proses; ( 8) Penelitiannya berkonteks mikro (Lexy J. Moleong, 1999).

Oleh karena itu dalam penelitian ini berusaha mengetahui dan mendeskripsikan dengan jelas tentang Analisis Kemampuan Manajerial dan Komunikasi Ketua Terhadap Kinerja Dosen Perguruan Tinggi Keagamaan Islam Swasta (PTKIS) di Kota Padang Sidempuan. 


\section{Tinjauan Pustaka dan Pengembangan Hipotesis Konsep Managemen}

Menurut Hasibuan (2005) mengemukakan bahwa "Manajemen adalah serangkaian kegiatan ilmu dan seni mengatur proses pemanfaatan sumber daya manusia dan sumber daya-sumber daya lainnya secara efektif dan efisien untuk suatu tujuan tertentu". James J. J (2008). mengatakan bahwa "manajemen sumber daya manusia adalah sebuah fungsi khusus manajemen yang lebih luas berkenaan dengan layanan yang harus dilakukan sekelompok individu dalam sebuah lembaga yang memperkerjakan mereka dan semua aktivitas yang berhubungan dengan mereka ditujukan untuk memfasilitasi sebuah keberhasilan organisasional".

Kata manajemen menurut Mochtar Effendy (1986) berasal dari bahasa inggris yakni dari kata to manage yang bersinonim dengan kata to handle yang berarti mengurus, to control memeriksa dan to guide yang berarti memimpin. Jadi apabila dilihat dari arti etimologi, manajemen berarti pengurusan, pengendalian dan pemimpin atau membimbing. Ramayulis (2008) menyatakan bahwa pengertian yang sama dengan hakikat manajemen adalah al-tadbir (pengaturan).

Sementara manajemen menurut istilah adalah proses mengkordinasikan aktifitasaktifitas kerja sehingga dapat selesai secara efesien dan efektif dengan dan melalui orang lain (Robbin dan Coulter, 2008). Sedangkan Sondang P (1990) mengartikan manajemen sebagai kemampuan atau keterampilan untuk memperoleh suatu hasil dalam rangka mencapai tujuan melalui kegiatan-kegiatan orang lain. Beberapa pendapat yang telah dikemukakan oleh para ahli, sehingga penulis berpandapat bahwa manajemen adalah suatu kegiatan pengaturan dalam suatu kepemimpinan untuk keberhasilan suatu organisasi agar tercapai dengan efektif dan efesien.

\section{Konsep Manajerial}

Keterampilan atau skill dapat diartikan kemampuan yaitu kemampuan dari seseorang untuk melakukan berbagai jenis kegiatan kognitif atau diperlukan dengan satu cara yang efektif (Gary Yulk, 1998). "Manajerial berasal dari kata manajer yang berarti orang yang menjadi pimpinan atau orang yang mengatur jadwal, membuat rencana." (W.J.S. Poerwodarminto, 2006) Manajer juga dapat diartikan sebagai orang yang bertanggungjawab atas hasil kerja orang-orang yang ada didalam organisasi (Suprapro, 2000).

Dari berbagai pengertian tersebut, maka penulis berpendapat bahwa kepemimpinan adalah kemampuan seorang pemimpinan untuk mempenga ruhi dan menggerakkan orang lain untuk bekerja sama mencapai suatu tujuan kelompok. Upaya untuk menilai sukses tidaknya pemimpin itu dilakukan antara lain dengan mengamati dan mencatat sifat-sifat dan kualitas atau mutu perilakunya, yang dipakai sebagai kriteria untuk menilai kepemimpinannya. Wahjo Sumidjo (2003), secara sederhana Ketua Perguruan Tinggi adalah "seorang tenaga fungsional memimpin guru yang diberi tugas untuk memimpin suatu Perguruan Tinggi dimana diselenggarakan proses belajar mengajar." Ketua Perguruan Tinggi sebagai manajer pada hakikatnya adalah seorang perencana, organisator, pemimpin dan seorang pengendali (Wahjo Sumidjo, 2003)."

\section{Pengertian Kinerja Dosen}

Kinerja merupakan sebuah proses komunikasi yang berkesinambungan dan dilakukan dalam kemitraan antara seorang guru dengan penyedia langsung (Robert Bacal, 2002). Proses ini meliputi kegiatan membangun harapan yang jelas dan pemahaman mengaenai pekerjaan yang akan dilakukan. Kinerja ini sebagai sebuah sistem, artinya bahwa kinerja memiliki sejumlah bagian yang semuanya harus diikutsertakan apabila sistem ini ingin memberikan nilai tambah bagi organisasi, pimpinan, dan guru itu sendiri. 
Kinerja seorang dosen merupakan hasil interaksi antara motivasi dengan kemampuan dasar. Adanya motivasi kerja tinggi yang dimiliki, belum tentu akan menghasilkan kinerja yang optimal apabila dia memiliki motivasi kerja yang kurang baik atau rendah, akan menghasilkan kinerja yang kurang optimal pula, meskipun ia memiliki kemampuan kerja yang tinggi. Sehingga penulis menyimpulkan bahwa kinerja merupakan hasil interaksi pemimpin dari motivasi kerja dan kemampuan kerja serta adanya tindakan dari pimpinan untuk bekerja sesuai dengan standar oprasional yang telah ditetapkan oleh pimpinannya.

\section{Metode Penelitian \\ Pendekatan Penelitian}

Berdasarkan fokus dan tujuan penelitian, maka penelitian ini merupakan kajian yang mendalam guna memperoleh data yang lengkap dan terperinci. Untuk itu penelitian ini menggunakan pendekatan deskriptif kualitatif. Penelitian deskriptif kualitatif. Menurut Best, seperti yang dikutip Sukardi adalah "metode penelitian yang berusaha menggambarkan dan menginterpretasikan objek sesuai dengan apa adanya" (Sukardi, 2005). Demikian juga Prasetya mengungkapkan bahwa "penelitian deskriptif adalah penelitian yang menjelaskan fakta apa adanya" (Prasetya Irawan, 1999).

Penelitian kualitatif merupakan penelitian yang temuannya diperoleh berdasarkan paradigma, strategi dan implementasi model secara kualitatif (Aminuddi, $\mathrm{tt}$ ). Sedangkan menurut Manca seperti yang dikutip oleh Moleong, Penelitian kualitatif memiliki ciri-ciri sebagai berikut: (1) Merupakan tradisi Jerman yang berlandaskan idealisme, humanisme, dan kulturalisme; (2) penelitian ini dapat menghasilkan teori, mengembangkan pemahaman, dan menjelaskan realita yang kompleks; ( 3 ) Bersifat dengan pendekatan induktif-deskriptif; (4) memerlukan waktu yang panjang; (5) Datanya berupa deskripsi, dokumen, catatan lapangan, foto, dan gambar; (6) Informannya "Maximum Variety"; (7) berorientasi pada proses; ( 8) Penelitiannya berkonteks mikro (Lexy J. Moleong, 1999).

Oleh karena itu dalam penelitian ini berusaha mengetahui dan mendeskripsikan dengan jelas tentang Analisis Kemampuan Manajerial dan Komunikasi Ketua Terhadap Kinerja Dosen Perguruan Tinggi Keagamaan Islam Swasta (PTKIS) di Kota Padang Sidempuan.

\section{Jenis Penelitian}

Ditinjau dari segi sifat-sifat data maka termasuk dalam penelitian Kualitatif yaitu penelitian yang bermaksud untuk memahami fenomena tentang apa yang dialami oleh subjek penelitian misalnya perilaku, persepsi, motivasi, tindakan dan lain-lain secara holistik, dan dengan cara deskripsi dalam bentuk kata-kata dan bahasa, pada suatu konteks khusus yang alamiah dan dengan memanfaatkan berbagai metode alamiah (Lexy J. Moleong, 2006).

\section{Tempat dan Waktu Penelitian}

Tempat Penelitian Penelitian ini dilaksanakan di Perguruan Tinggi Keagamaan Islam Swasta (PTKIS) di Kota Padang Sidempuan, yang berjumlah 3 Perguruan Tinggi. Adapun pelaksanaan penelitian ini dilaksanakan pada bulan Jannuari-Juli 2021.

\section{Data dan Sumber Data}

Data yang diperlukan dalam penelitian ini dapat dikelompokkan menjadi dua, antar lain, Sumber data primer adalah sumber data penelitian yang diperoleh secara langsung dari sumber asli (tidak melalui media perantara) (Nana Sudjana Ibrahim, 1984). Dalam penelitian ini sumber data primernya yakni sumber data yang diperoleh dan dikumpulkan langsung dari informan yang terdiri dari Ketua Perguruan Tinggi Keagamaan Islam Swasta (PTKIS) di Kota Padang Sidempuan sebanyak 3 orang. Sumber data sekunder adalah sumber data penelitian yang diperoleh secara tidak langsung melalui media perantara (diperoleh dan di catat oleh 
pihak lain) (Marzuki, 1991). Adapun data sekunder untuk penelitian ini diambil dari buku penunjang dan data hasil observasi yang berkaitan dengan fokus penelitian. Semua data tersebut diharapkan mampu memberikan deskripsi tentang Kemampuan Manajerial dan Komunikasi Ketua Terhadap Kinerja Dosen Perguruan Tinggi Keagamaan Islam Swasta (PTKIS) di Kota Padang Sidempuan.

\section{Teknik Pengumpulan Data}

Dalam penelitian di samping perlu menggunakan metode penelitian yang tepat, juga perlu memilih teknik dan alat pengumpulan data yang relevan. Penggunaan teknik operasional dan alat pengumpulan data yang tepat memungkinkan diperolehnya data yang objektif. Adapun teknik pengumpulan data yang digunakan dalam penelitian ini adalah, Angket dan , Observasi dan Dokumentasi

\section{Hasil Penelitian dan Pembahasan \\ Pembinaan Istrumen}

Pengembangan instrumen Manajerial Dan Komunikasi Terhadap Kinerja Dosen Perguruan Tinggi Keagamaan Islam Swasta (PTKIS) Di Padangsidempuan menggunakan tiga tahap pendekatan, yaitu: tahap 1, dimulai dengan identifikasi skala; tahap 2, melibatkan penulisan item individu dalam skala; dan tahap 3, melibatkan item pengujian lapangan diikuti oleh analisis item dan prosedur validasi. Berikut akan disajikan deskripsi langkah-langkah yang dilakukan oleh peneliti.

\section{Tahap 1 - Identifikasi dan Pengembangan Skala}

Tahap 1 terdiri dari tiga langkah yang mengarah pada identifikasi dan pengembangan skala. Langkah pertama termasuk meninjau literatur yang terkait dengan instrumen Manajerial Dan Komunikasi Terhadap Kinerja Dosen Perguruan Tinggi Keagamaan Islam Swasta (PTKIS) Di Padangsidempuan sebagian besar diadaptasi dari teori J. David Hunger dan Thomas L. Wheelen (2009) yang terdiri atas 13 konstruk (McClellan \& Conti, 2008) dan kajian-kajian lain yang berkaitan. Langkah penting ini berusaha mengidentifikasi komponenkomponen utama yang akan dipertimbangkan oleh Dosen dan pimpinan perguruan tinggi. Langkah kedua adalah melakukan diskusi kelompok terfokus dengan sekelompok dosen yang berpengalaman untukmemperoleh saran tentang Manajerial Dan Komunikasi Terhadap Kinerja Dosen Perguruan Tinggi Keagamaan Islam Swasta (PTKIS) Di Padangsidempuan. Selain itu, peneliti juga meminta persetujuan dan kebenaran terhadap konstruk dan item yang dibina dalam instrument tersebut. Langkah ketiga adalah untuk mengklasifikasikan dan mengatur kembali skala yang baru dikembangkan terkait Manajerial Dan Komunikasi Terhadap Kinerja Dosen Perguruan Tinggi Keagamaan Islam Swasta (PTKIS) Di Padangsidempuan, sesuai yang disarankan para pakar (ahli). Manajerial Dan Komunikasi Terhadap Kinerja Dosen Perguruan Tinggi Keagamaan Islam Swasta (PTKIS) Di Padangsidempuan dalam penelitian ini mencakup sembilan komponen utama, yaitu: 1) Keahlian teknis; 2) Keahlian manusia; 3) Keahlian konseptual; 4) Interaksi yang dinamis; 5) Pengaturan hak, kewajiban, tugas, wewenang, peran dan fungsi; 6) Distribusi kekuasaan; 7) Interdependensi (saling ketergantungan); 8) Orientasi dan tujuan yang sama; 9) Kuantitas dari hasil; 10) Kualitas dari hasil; 11) Ketepatan waktu dari hasil; 12) Kehadiran; 13) Kemampuan bekerja sama.

\section{Tahap-Menulis Item Individual}

Berdasarkan instrumen Manajerial Dan Komunikasi Terhadap Kinerja Dosen Perguruan Tinggi Keagamaan Islam Swasta (PTKIS) Di Padangsidempuan, peneliti menyusun seperangkat kuesioner dimana setiap komponen Manajerial Dan Komunikasi Terhadap Kinerja Dosen Perguruan Tinggi Keagamaan Islam Swasta (PTKIS) Di Padangsidempuan terdiri dari konstruksi-konstruksi yang merupakan panduan untuk mengembangkan 
seperangkat kuesioner dalam mengenali Manajerial Dan Komunikasi Terhadap Kinerja Dosen Perguruan Tinggi Keagamaan Islam Swasta (PTKIS) Di Padangsidempuan di kalangan tutor. Berikut akan disajikan seluruh rangkaian item Manajerial Dan Komunikasi Terhadap Kinerja Dosen Perguruan Tinggi Keagamaan Islam Swasta (PTKIS) Di Padangsidempuan yang ditunjukkan ke panel ahli untuk memastikan validasi konstruk dan konten instrumen berikut table instrument penelitian.

Table 01 : Penentuan instrumen penelitian pengaruh kemampuan manajerial dan komunikasi ketua perguruan tinggi terhadap kinerja dosen pada perguruan tinggi keagamaan islam swasta (ptkis) di padangsidimpuan.

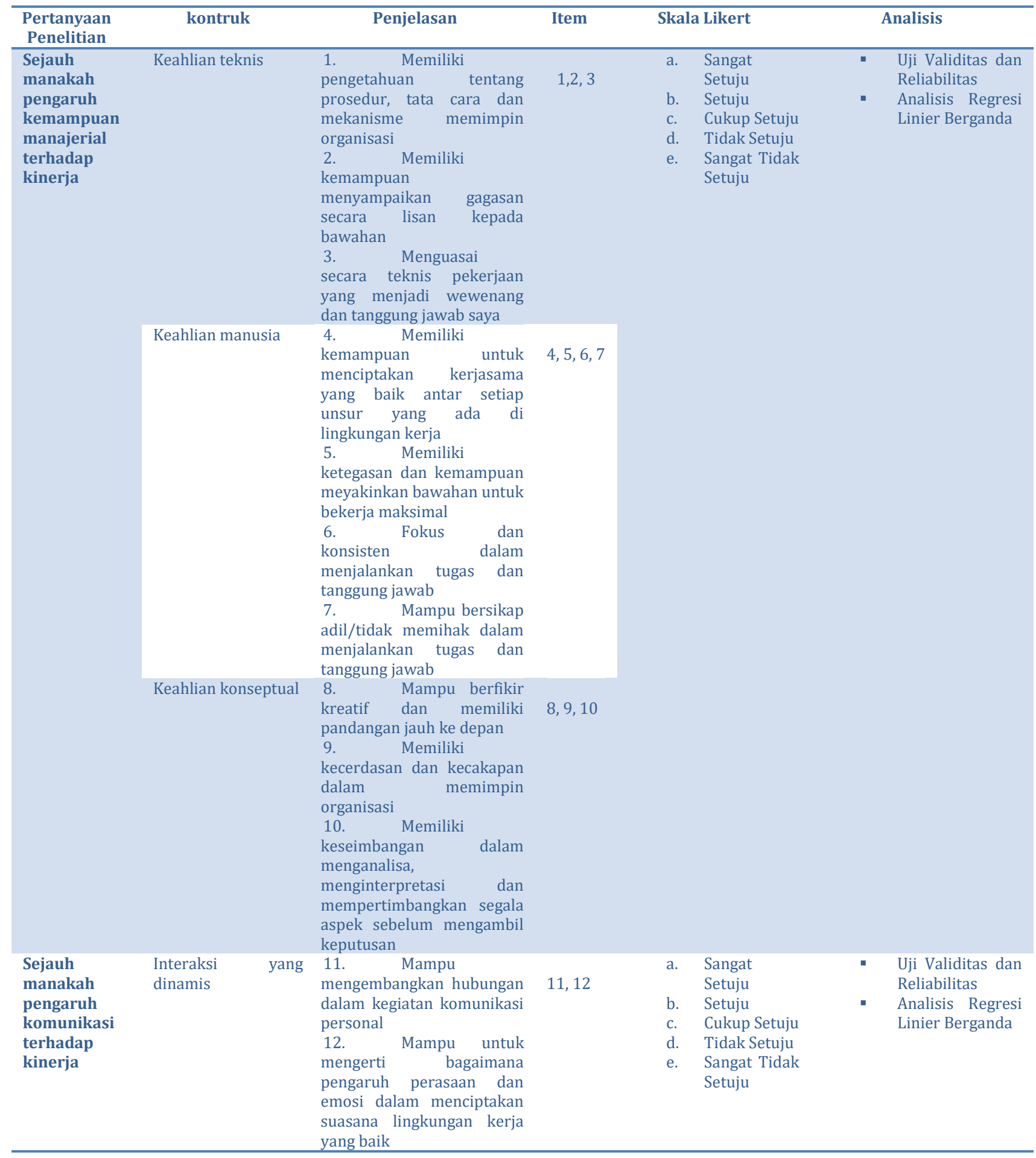




\begin{tabular}{|c|c|c|c|c|c|c|c|}
\hline & $\begin{array}{ll}\text { Pengaturan } & \text { hak, } \\
\text { kewajiban, } & \text { tugas, } \\
\text { wewenang, } & \text { peran } \\
\text { dan fungsi. } & \end{array}$ & $\begin{array}{l}\text { 13. Mampu } \\
\text { berkomunikasi dengan } \\
\text { menggunakan seluruh } \\
\text { pengetahuan dan persepsi } \\
\text { dalam pengaturan tugas } \\
\text { dan tanggung jawab kerja } \\
\begin{array}{l}\text { 14. Mampu } \\
\text { berkomunikasi dengan } \\
\text { bawahan agar dapat } \\
\text { berkontribusi maksimal } \\
\text { dalam bekerja }\end{array}\end{array}$ & 13,14 & & & & \\
\hline & $\begin{array}{l}\text { Distribusi } \\
\text { kekuasaan. }\end{array}$ & $\begin{array}{l}15 . \quad \text { Mampu } \\
\text { menjadikan bawahan lebih } \\
\text { produktif } \\
16 . \quad \text { Mampu } \\
\text { membuat/memberikan } \\
\text { pemahaman yang lebih baik } \\
\text { kepada bawahan }\end{array}$ & 15,16 & & & & \\
\hline & $\begin{array}{l}\text { Interdependensi } \\
\text { (saling } \\
\text { ketergantungan) }\end{array}$ & $\begin{array}{l}\begin{array}{l}17 . \\
\text { sistem } \\
\text { transparan } \\
18 . \quad \text { komunikasi } \\
\text { mengatasi konflik yang } \\
\text { terjadi di lingkungan kerja }\end{array}\end{array}$ & 17,18 & & & & \\
\hline & $\begin{array}{l}\text { Orientasi dan tujuan } \\
\text { yang sama }\end{array}$ & $\begin{array}{l}19 . \quad \text { Mampu } \\
\text { membangun hubungan } \\
\text { yang baik dengan bawahan } \\
20 . \quad \text { Mampu } \\
\text { menumbuhkan } \\
\text { kepercayaan bawahan }\end{array}$ & 19,20 & & & & \\
\hline \multirow{5}{*}{$\begin{array}{l}\text { Sejauh } \\
\text { manakah } \\
\text { pengaruh } \\
\text { kemampuan } \\
\text { manajerial } \\
\text { dan } \\
\text { komunikasi } \\
\text { terhadap } \\
\text { kinerja }\end{array}$} & Kuantitas dari hasil & $\begin{array}{l}\text { 21. Persiapan RPS } \\
\text { 22. Persiapan } \\
\text { materi perkuliahan }\end{array}$ & 21,22 & \multirow{5}{*}{\multicolumn{2}{|c|}{$\begin{array}{ll}\text { a. } & \text { Sangat baik } \\
\text { b. } & \text { Baik } \\
\text { c. } & \text { Cukup Baik } \\
\text { d. } & \text { Tidak Baik } \\
\text { e. } & \text { Sangat Tidak } \\
& \text { Baik }\end{array}$}} & & \multirow{5}{*}{$\begin{array}{l}\text { Uji Validitas dan } \\
\text { Reliabilitas } \\
\text { Analisis Regresi } \\
\text { Linier Berganda }\end{array}$} \\
\hline & Kualitas dari hasil & $\begin{array}{l}23 . \quad \text { Kesesuaian } \\
\text { penyampaian materi } \\
\text { perkuliahan dengan RPS } \\
\text { yang dibuat } \\
24 . \quad \text { Menggunakan } \\
\text { metode pembelajaran } \\
\text { sesuai dengan tujuan } \\
\text { perkuliahan }\end{array}$ & 23,24 & & & & \\
\hline & $\begin{array}{l}\text { Ketepatan waktu } \\
\text { dari hasil }\end{array}$ & $\begin{array}{l}25 . \quad \text { Menyelesaikan } \\
\text { perkuliahan sesuai dengan } \\
\text { yang dijadwalkan } \\
26 . \quad \text { Menyampaikan } \\
\text { seluruh materi perkuliahan } \\
\text { sesuai RPS dan jadwal }\end{array}$ & 25,26 & & & & \\
\hline & Kehadiran & $\begin{array}{l}27 . \quad \text { Kedisiplinan } \\
\text { waktu penyelenggaraan } \\
\text { perkuliahan } \\
28 . \quad \text { Kedisiplinan } \\
\text { pelaporan kehadiran dan } \\
\text { penyelenggaraan } \\
\text { perkuliahan }\end{array}$ & 27,28 & & & & \\
\hline & $\begin{array}{l}\text { Kemampuan bekerja } \\
\text { sama }\end{array}$ & $\begin{array}{l}29 . \quad \text { Memberikan } \\
\text { bimbingan akademik } \\
\text { kepada mahasiswa } \\
30 . \quad \text { Mampu } \\
\text { bekerjasama dengan } \\
\text { seluruh unsur perguruan } \\
\text { tinggi }\end{array}$ & 29,30 & & & & \\
\hline
\end{tabular}

\section{Tahap 3-Analisis Validasi dan Reliabilitas Istrumen}

Salah satu tahap dalam penelitian ini yang paling penting adalah perancangan instrumen pengukuran yang dilengkapi dengan uji validitas dan reliabilitasnya. Validitas konstruk menunjukkan sejauh mana alat ukur mengungkapkan suatu konstruk teoritis yang hendak

Hasil Uji Validitas dan Reliabilitas Kuesioner Penelitian tentang Manajerial Ketua Perguruan Tinggi dengan menggunakan SPSS (Statistical Product and Service Solution) 


\begin{tabular}{|l|l|c|c|}
\hline \multicolumn{1}{|l|}{ Descriptive Statistics } & $\begin{array}{c}\text { Std. } \\
\text { Deviation }\end{array}$ & N \\
\hline & Mean & .346 & 30 \\
\hline SkorKues.1 & 4.13 & .379 & 30 \\
SkorKues.2 & 4.17 & .379 & 30 \\
SkorKues.3 & 4.17 & .346 & 30 \\
SkorKues.4 & 4.13 & .305 & 30 \\
SkorKues.5 & 4.10 & .379 & 30 \\
SkorKues.6 & 4.17 & .379 & 30 \\
SkorKues.7 & 4.17 & .305 & 30 \\
SkorKues.8 & 4.10 & .346 & 30 \\
SkorKues.9 & 4.13 & .379 & 30 \\
SkorKues.10 & 4.17 & & \\
\hline
\end{tabular}

Tabel Descriptive Statistic di atas menjelaskan bahwa:

$>$ Yang menjadi sampel ada 30 orang

$>$ Rata-rata jawaban skor kuesioner 1 sebesar 4,13 ; skor kuesioner 2 sebesar 4,17; skor kuesioner 3 sebesar 4,17 ; skor kuesioner 4 sebesar 4,13; skor kuesioner 5 sebesar 4,10 ; skor kuesioner 6 sebesar 4,17 ; skor kuesioner 7 sebesar 4,17 ;skor kuesioner 8 sebesar 4,10 ; skor kuesioner 9 sebesar 4,13 ; skor kuesioner 10 sebesar 4,17 .

Tabel Correlations di atas menjelaskan bahwa: Hasil uji validitas data menunjukkan semua butir pernyataan dari Kuesioner Manajerial Ketua Perguruan Tinggi adalah valid, karena nilai $r$ hitung lebih besar dari $r$ tabel $=0,707$

\begin{tabular}{|l|l|}
\hline \multicolumn{2}{|l|}{ Reliability Statistics } \\
\hline Cronbach's Alpha & N of Items \\
\hline .966 & 10 \\
\hline
\end{tabular}

Tabel Reliability Statistics di atas menunjukkan bahwa: Hasil uji reliabilitas data menunjukkan semua butir pernyataan dari Kuesioner Manajerial Ketua Perguruan Tinggi adalah reliabel, karena nilai $\mathrm{r}_{11}=0,966>0,6$

\section{Hasil Uji Validitas dan Reliabilitas Kuesioner Penelitian tentang Komunikasi Ketua Perguruan Tinggi dengan menggunakan SPSS (Statistical Product and Service Solution)}

Descriptive Statistics
\begin{tabular}{|l|l|l|l|}
\hline & Mean & Std. Deviation & N \\
\hline SkorKues.1 & 4.13 & .346 & 30 \\
SkorKues.2 & 4.17 & .379 & 30 \\
SkorKues.3 & 4.17 & .379 & 30 \\
SkorKues.4 & 4.13 & .346 & 30 \\
SkorKues.5 & 4.17 & .379 & 30 \\
SkorKues.6 & 4.10 & .305 & 30 \\
SkorKues.7 & 4.13 & .346 & 30 \\
SkorKues.8 & 4.17 & .379 & 30 \\
SkorKues.9 & 4.10 & .305 & 30 \\
SkorKues.10 & 4.13 & .346 & 30 \\
\hline
\end{tabular}

Tabel Descriptive Statistic di atas menjelaskan bahwa:

$>$ Yang menjadi sampel ada 30 orang

$>$ Rata-rata jawaban skor kuesioner 1 sebesar 4,13 ; skor kuesioner 2 sebesar 4,17 ; skor kuesioner 3 sebesar 4,17 ; skor kuesioner 4 sebesar 4,13; skor kuesioner 5 sebesar 
4,17 ; skor kuesioner 6 sebesar 4,10 ; skor kuesioner 7 sebesar 4,13 ; skor kuesioner 8 sebesar 4,17 ; skor kuesioner 9 sebesar 4,10 ; skor kuesioner 10 sebesar 4,13 .

Tabel Correlations di atas menjelaskan bahwa: Hasil uji validitas data menunjukkan semua butir pernyataan dari Kuesioner Komunikasi Ketua Perguruan Tinggi adalah valid, karena nilai $r_{\text {hitung }}$ lebih besar dari $r_{\text {tabel }}=0,707$

Reliability Statistics
\begin{tabular}{|c|c|}
\hline $\begin{array}{c}\text { Cronbach's } \\
\text { Alpha }\end{array}$ & $\begin{array}{r}\text { of } \\
\text { Items }\end{array}$ \\
\hline .973 & 10 \\
\hline
\end{tabular}

Tabel Reliability Statistics di atas menunjukkan bahwa:

Hasil uji reliabilitas data menunjukkan semua butir pernyataan dari Kuesioner Komunikasi Ketua Perguruan Tinggi adalah reliabel, karena nilai $r_{11}=0,973>0,6$

\section{Hasil Uji Validitas dan Reliabilitas Kuesioner Penelitian tentang Kinerja Dosen dengan menggunakan SPSS (Statistical Product and Service Solution)}

Descriptive Statistics

\begin{tabular}{|l|l|l|l|}
\hline & Mean & Std. Deviation & $\mathrm{N}$ \\
\hline SkorKues.1 & 4.13 & .346 & 30 \\
SkorKues.2 & 4.17 & .379 & 30 \\
SkorKues.3 & 4.17 & .379 & 30 \\
SkorKues.4 & 4.13 & .346 & 30 \\
SkorKues.5 & 4.17 & .379 & 30 \\
SkorKues.6 & 4.10 & .305 & 30 \\
SkorKues.7 & 4.17 & .379 & 30 \\
SkorKues.8 & 4.10 & .305 & 30 \\
SkorKues.9 & 4.10 & .305 & 30 \\
SkorKues.10 & 4.13 & .346 & 30 \\
\hline
\end{tabular}

Tabel Descriptive Statistic di atas menjelaskan bahwa:

$>$ Yang menjadi sampel ada 30 orang

$>$ Rata-rata jawaban skor kuesioner 1 sebesar 4,13 ; skor kuesioner 2 sebesar 4,17 ; skor kuesioner 3 sebesar 4,17 ; skor kuesioner 4 sebesar 4,13; skor kuesioner 5 sebesar 4,17 ; skor kuesioner 6 sebesar 4,10 ; skor kuesioner 7 sebesar 4,17 ; skor kuesioner 8 sebesar 4,10; Tabel Correlations di atas menjelaskan bahwa:

> Hasil uji validitas data menunjukkan semua butir pernyataan dari Kuesioner Kinerja

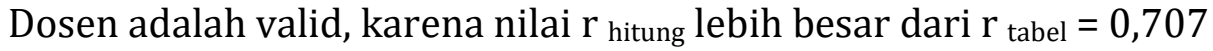




\section{Reliability Statistics}

\begin{tabular}{|l|c|}
\hline Cronbach's Alpha & $\begin{array}{c}\mathrm{N} \\
\text { Items }\end{array}$ \\
\hline .974 & 10 \\
\hline
\end{tabular}

Tabel Reliability Statistics di atas menunjukkan bahwa: Hasil uji reliabilitas data menunjukkan semua butir pernyataan dari Kuesioner Kinerja Dosen adalah reliabel, karena nilai $\mathrm{r}_{11}=0,974>0,6$

\section{Kesimpulan}

Berdasarkan hasil penelitian dan pembahasan diperoleh simpulan bahwa instrumen Pengembangan Instrumen Manajerial Dan Komunikasi Terhadap Kinerja Dosen Perguruan Tinggi Keagamaan Islam Swasta (PTKIS) Di Padangsidempuan adalah Manajerial Ketua Perguruan Tinggi adalah valid, karena nilai $r$ hitung lebih besar dari $r$ tabel $=0,707$. Hasil uji reliabilitas data menunjukkan semua butir pernyataan dari Kuesioner Manajerial Ketua Perguruan Tinggi adalah reliabel, karena nilai $r_{11}=0,966>0,6$. Hasil uji reliabilitas data menunjukkan semua butir pernyataan dari Kuesioner Komunikasi Ketua Perguruan Tinggi adalah reliabel, karena nilai $r_{11}=0,973>0,6$. Hasil uji reliabilitas data menunjukkan semua butir pernyataan dari Kuesioner Kinerja Dosen adalah reliabel, karena nilai $r_{11}=0,974>0,6$

\section{Daftar Pustaka}

A.A Anwar Prabu Mangkunegara, Manajemen Sumber Data Perusahaan, (Bandung: PT. Refieka Aditema, 2004),

Ahmad Susanto, Manajemen Peningkatan Kinerja Guru, (Depok: Prendamedia Group : 2018)

Arni Muhammad. Komunikasi Organisasi (Jakarta: Bumi Aksara, 2005),

Aswarni Sudjud,Metodologi penelitian pendidikan, Yogyakarta : AP FIP IKIP Yogyakarta, 1989)

B. Curtis, James J. Floyd, dan Jerril L. Winsor, Komunikasi Bisnis \& Profesional (Bandung: PT Remaja Rosdakarya, 2005),

Badri Munir Sukoco, Manajemen Administrasi Perkantoran Modern, (Jakarta: Erlangga, 2000)

Deddy Mulyana, Ilmu Komunikasi Suatu Pengantar (Bandung: PT Remaja Rosdakarya, 2007)

Dede Rosyada, Paradigma Pendidikan Demokratis: Sebuah Model Pelibatan Masyarakat dalam Penyelenggaraan Pendidikan, (Jakarta:PT Kencana, 2004),

Departemen Agama RI, Al Hikmah Al Qur'an dan Terjemahannya, (Bandung : CV Penerbit Diponegoro, 2014)

Departemen Pendidikan Dan Kebudayaan Republic Indonesia, Kamus Besar Bahasa Indonesia, (Jakarta: Perum balai pustaka, 1988),

Depdiknas, Tentang Guru dan Dosen, (Jakarta : Balai Pustaka, 2008),

E .Mulyasa, Menjadi Kepala Sekolah Profesional, (Bandung: PT. Remaja Rosda Karya, 2011)

Manajemen berbasis Sekolah: Konsep, Strategi dan Implementasi, (Bandung: PT. Remaja Rosda Karya, 2002)

Kurikulum Berbasis Kompetensi : Konsep , Karakteristik, dan Implementasi.

(Bandung : Remaja Rosda Karya, 2005)

Menjadi Guru Profesional, (Bandung : Remaja Rosda Karya, 2008),

E. Depari, dan C. MacAndrews, (eds), Peranan Komunikasi Massa dalam Pembangunan

(Yogyakarta: Gadjah Mada University Press. 1998),

Elvinaro Ardianto, Komunikasi Massa: Suatu Pengantar (Bandung: Simbiosa Rekatama Media. 2004),

Endang Kusmiati, Hubungan Keterampilan Manajer Kepala Sekolah dengan Kinerja Guru SekolahDasar di Kecamatan Suko Manunggal Kota Surabaya, (Tesis, UNY, 2010) 
F. Rachmadi, Public Relations Dalam Teori Dan Praktek (Jakarta: Gramedia, 1996)

Fattah, Landasan Manajemen Pendidikan Remaja, (Bandung: Rosda Karya, 1999)

Fred N. Kerlinger, Asas-Asas Penelitian Behavioral, Terjemahan Bandung R. Simantupang, Gadjah Mada University Press. Yogyakarta. 1990

Group, 2006),

Hafied Cangara, Pengantar Ilmu Komunikasi (Jakarta: Raja Grafindo Persada, 2011),

Hani Handoko, Manajemen, (Yogyakarta: BPFE. (1995),

Hasibuan, Malayu S. P. Manajemen Sumber Daya Manusia. (Jakarta: Bumi Aksara, 2005)

Hasil observasi kepada guru di MA Hidayatul Mubtadiin Jati Agung pada tanggal 25 September 2019 jam 10:00, Kepala MA Hidayatul Mubtadiin Jati Agung 25 September 2019 jam 09:35

Hendiyat Soetopo.Kepemimpinan dan Supervisi Pendidikan. (Jakarta: Bina Aksara, 1984) Miftah Thoha, Kepemimpinan dalam Manajemen, (Jakarta: Raja Grafindo Persad: 1995)

Husaini Usman, Manajemen: teori, Praktik, dan Riset Pendidikan, (Bandung : Bumi Aksara, 2006)

Husnul Yaqin, Administrasi dan Manajamen Pendidikan, (Banjarmasin : IAIN Antasari Press, 2011)

Imam Musbikin, Menjadi Kepala Sekolah yang Hebat, (Pekanbaru: Zanafa Publishing 2013)

Menjadi Kepala Sekolah yang Hebat, Pekanbaru: Zanafa Publishing 2013

John Davis, \& Goldberg Ray. A Concept of Agribusiness. Div of Research. Grad. School of Business Administration (Boston: Harvard University. 1975),

John M. Invancevich, robert Konopaske, Michael T. Matteson, Perilaku Dan Manajemen, . Ivancevich, Robert Konopaske, Michael T. Matteson, Perilaku Dan Manajemen Organisasi (Jakarta:PT Erlangga, 2006),

Jones James J. Human Resource Managament in Education (Manajemen Sumber Daya Manusia dalam Pendidikan. Jakarta : Q-Media 2008)

Joseph A DeVito,.The Interpersonal Communication Book (Jakarta: Professional Book. 1989),

Keith Davis dan John W. Newstorm, Perilaku dalam Organisasi, Edisi Kesembilan, diterjemahkan oleh Agus Dharma (Jakarta: Erlangga, 1993),

Perilaku dalam Organisasi, Edisi Kesembilan, diterjemahkan oleh Agus Dharma

(Jakarta: Erlangga, 1993),

Kemendiknas, Buku Kerja Kepala Sekolah, (Jakarta: Pusat Pengembangan Tenaga Kependidikan, 2011)

M. Ngalim Purwanto, Administrasi dan Supervisi Pendidikan, (Jakarta: Remaja Rosdakarya, 2003),

Marhaeni Fajar, Ilmu Komunikasi Teori \& Praktik (Yogyakarta: Graha ilmu, 2009)

Marno dan Triyo Supriyatno, Manajemen dan Kepemimpinan Pendidikan islam,( Bandung: Rafika Aditama, 2008)

Martinis Yamin, Standarisasi Kinerja Guru, (Jakarta: Persada Press, 2010), Standarisasi Kinerja Guru, (Jakarta: Persada Press, 2010), 